\title{
Comparison of Safety and Efficacy of Potassium Hydroxide versus Combination of Salicylic and Lactic Acid for Molluscum Contagiosum
}

\author{
Durre-Shehwar Arshad Pirzada ${ }^{1}$, Sumaira Abdullah², Qurat-ul Ain Zia ${ }^{3}$, Syed Afaq Ahmed ${ }^{4}$, Hamid Ali ${ }^{5}$ \\ 1 Private Practitioner in Abbotabad \\ 2 Senior Registrar, Department of Dermatology, Akbar Niazi Teaching Hospital \\ ${ }^{3}$ Senior Lecturer, Department of Biochemistry, Islamabad Medical \& Dental College \\ ${ }^{4}$ Head, Department of Dermatology, Dr. Akbar Niazi Teaching Hospital \\ ${ }^{5}$ Head, Department of Medical Lab Technology, Dr. Akbar Niazi Teaching Hospital
}

\begin{abstract}
Background: Molluscum contagiosum (MC) is a contagious cutaneous infection caused by $\mathrm{MC}$ virus, affecting mainly the pediatric population. It is characterized by flesh-colored umbilicated papules occurring on the skin surface. Potassium hydroxide (KOH) and salicylic acid plus lactic acid combination being keratolytic agents, are effective treatment options. The objective of the study was to compare the efficacy and safety of $10 \% \mathrm{KOH}$ solution versus salicylic acid/ lactic acid combination in treating Molluscum contagiosum in pediatric population.

Material and Methods: A total of 80 children (age range 1-13 years) with Molluscum contagiosum lesions were selected from the Dermatology Out-Patient Department, and were randomly allocated into two groups by lottery method. Group A was given topical $10 \% \mathrm{KOH}$ solution and group B was given Salicylic Plus Lactic acid preparations for topical application. Patients were followed after two weeks to see regression in size of the lesion, and development of any side-effects. Final visit was scheduled at 6 weeks. Statistical analysis was carried out using SPSS (version 16) with $p$ value less than 0.05 considered as statistically significant.

Results: Patients with MC $(n=80)$ were equally divided into group A (treated with $10 \% \mathrm{KOH}$ ) and group $B$ (treated with combination of Salicylic acid and Lactic acid). After 6 weeks, complete remission from Molluscum contagiosum virus was seen in $29(72.5 \%)$ patients of group A and $34(85 \%)$ patients of group B. There were $12(30 \%)$ patients in group A who developed local irritation and 4 $(10 \%)$ developed local erythema after 6 weeks. None of the patients of group B had any such side effects.

Conclusion: $10 \% \mathrm{KOH}$ solution is as effective as the combination of Salicylic and Lactic acids for treatment of Molluscum contagiosum in pediatric population, however it is associated with side effects of local irritation and erythema.

Key words: Molluscum contagiosum; potassium hydroxide; salicylic acid, lactic acid combination; topical

Authors' Contribution:

1,2 Conception, synthesis, planning of

research and manuscript writing

Interpretation, discussion, ${ }^{3-5}$ Active

participations in data collection

Data analysis.

Cite this article. Pirzada DA, Abdullah S, Zia Q, Ahmed SA, Ali H. Comparison of Safety and

Efficacy of Potassium Hydroxide versus Salicylic Acid and Lactic Acid Combination for

Treatment of Molluscum Contagiosum. J Islamabad Med Dental Coll.2019; 8(3):131-134.

doi: $10.35787 /$ jimdc.v8i3.418

Article info:

Received: December 6, 2018

Accepted: May 10, 2019

Email: quratulain_imdc@yahoo.com

Funding Source: Nil

Conflict of Interest: Nil
\end{abstract}

\section{Introduction}

Molluscum contagiosum (MC) is a common viral infection in children caused by MC virus, a member of pox virus family, belonging to genus molluscipoxvirus. ${ }^{1} \mathrm{MC}$ presents as pearly white papules with central depression, they can affect any part of the skin surface. ${ }^{1} \mathrm{~A}$ casecontrol study, compiling data for infected children $(<5$ years old) at an Indian Health Service (IHS) outpatient clinic in the United States reported an overall incidence of 
68.5 per 10,000 children. $^{2}$ This viral infection spreads by scratching, sharing towels/clothing or using community swimming pools. ${ }^{2}$ Molluscum contagiosum is a selflimiting condition, and spontaneous resolution occurs within 6-18 months. The need for treatment arises as the lesions are very contagious and a source of embarrassment both for the patient and parents. ${ }^{3}$

Various treatments are available, aimed at destroying the infected tissue with the virus including curettage, electrocoagulation, topical keratolytic therapies like salicylic acid, $\mathrm{KOH}$, or tretinoins and oral drugs like cimetidine and isotretinoin. ${ }^{4} \mathrm{~A}$ comparative study on the effect of $10 \% \mathrm{KOH}$ and combination of salicylic plus lactic acid in treating childhood MC concluded that $83.3 \%$ of patients treated with $\mathrm{KOH}$ and $100 \%$ patients treated with salicylic and lactic acid combination showed complete resolution with minimal side effects. ${ }^{5}$

$\mathrm{KOH}$ solution is a cheap chemical and is freely available, while salicylic acid and lactic acid combination is also available as an over-the-counter drug. However, less data is on record regarding their safety and efficacy profile. This study helped us in determining the safety and efficacy profile of these drugs, thus finding a cost-effective and safer treatment option for Molluscum contagiosum in pediatric population.

\section{Material and Methods}

This randomized control trial (RCT) was carried out at Dermatology outpatient department, Pakistan Institute of Medical Sciences (PIMS), Islamabad from February, 2015 to August, 2015. Sample size was calculated with the help of WHO calculator. Level of significance was kept as a = $5 \%$, power of the study $80 \%, P 1=83.3 \% 5$ and $P 2=100 \% 5$ Calculated sample size was 40 patients in each group. A total of 80 patients were recruited by consecutive nonprobability sampling. Patients from 1-13 years of age suffering from molluscum contagiosum presenting to Dermatology outpatient department, Pakistan Institute of Medical Sciences, Islamabad were included. All immunocompromised patients (congenital or acquired) and patients having other topical treatment within the last month were excluded from study.
The study commenced after approval from the Hospital's Ethical Review Board. Written informed consent was taken from the parents of the patients registered for study. Confidentiality was maintained throughout the study. All enrolled patients were divided into Group A and Group B randomly by lottery method. Single blinded protocol was followed by concealing any information about their allotment group from the patient/parents.

Group A was given $10 \% \mathrm{KOH}$ solution once a day, and group B was prescribed salicylic acid and lactic acid combination (active control) to be applied on MC lesions once a day. Parents were instructed to apply these drugs on the lesions. Either of the treatment regimens was discontinued, if the patient developed any of the side effects like erythema, ulceration, scaling and hyperpigmentation. All patients were asked to follow-up fortnightly, and at each visit lesions were examined for decrease in size and development of any side effects. Final visit was scheduled at 6 weeks. No patient was lost to follow up.

Safety is defined in terms of absence of erythema, ulceration, scaling and hyperpigmentation, and efficacy is defined in terms of complete resolution of lesions in six weeks. All statistical calculations were performed using SPSS version 16. Mean and standard deviation were calculated for age and duration of the disease. Frequency and percentages were calculated for categorical variables such as gender, efficacy and safety. Chi square test was used to compare categorical variables. $P$ value of less than 0.05 was considered statistically significant

\section{Results}

The demographic characteristics of participants of both groups are shown in Table I. Regarding efficacy, a greater number of patients $(n=34)$ in group $B$ using salicylic acid and lactic acid combination had complete remission as compared to patients in group $A(n=29)$ using $\mathrm{KOH}$ therapy, but the difference was statistically nonsignificant. However, $30 \%$ of patients in group A developed local irritation and 10\% developed erythema and the difference was statistically significant (Table II). 


\begin{tabular}{|l|c|c|}
\hline \multicolumn{4}{|c|}{ Table I: Demographic characteristics of Participants of Study } \\
\hline No. of patients (80) & $\begin{array}{c}\text { Group A } \\
(\mathbf{4 0})\end{array}$ & $\begin{array}{c}\text { Group B } \\
(\mathbf{4 0})\end{array}$ \\
\hline Mean Age (years) & 5.28 & 4.68 \\
\hline Mean Duration of disease (months) & 3.83 & 3.63 \\
\hline Males n (\%) & $19(47.5)$ & $18(45)$ \\
\hline Females n (\%) & $21(52.5)$ & $22(55)$ \\
\hline
\end{tabular}

Table II: Comparison of Efficacy and Safety in both the groups

\begin{tabular}{|l|l|c|c|c|}
\hline \multicolumn{1}{|c|}{$(\mathbf{n = 8 0 )}$} \\
\hline & $\begin{array}{c}\text { Variables } \\
\text { (after 06 weeks) }\end{array}$ & $\begin{array}{c}\text { Group A } \\
\mathbf{n}(\%)\end{array}$ & $\begin{array}{c}\text { Group B } \\
\mathbf{n}(\%)\end{array}$ & $P$-value \\
\hline Efficacy & $\begin{array}{l}\text { Complete MC } \\
\text { remission }\end{array}$ & $29(72.5)$ & $34(85.0)$ & 0.274 \\
\hline Safety & Local irritation & $12(30.0)$ & $0(0)$ & $0.000^{*}$ \\
\hline & Erythema & $04(10.0)$ & $0(0)$ & $0.040^{*}$ \\
\hline & Ulceration & $0(0)$ & $0(0)$ & NA \\
\hline \multicolumn{6}{|l|}{ Hyperpigmentation } & $0(0)$ & $0(0)$ & NA \\
\hline
\end{tabular}

\section{Discussion}

Molluscum contagiosum is a viral infection usually occurs in childhood but is also observed in adults especially those who are immunocompromised. ${ }^{1}$ It is usually a selflimiting condition but the need for treatment arises when the lesions disseminate, become pruritic or become a cause of discomfort for the patient. Various treatment options are available which range from destructive modalities like curettage, surgical excision or cryotherapy to milder forms like application of topical agents. 6,7

In the present study, the mean age was $5.28 \pm 3$ years in group A and $4.68 \pm 3.3$ years in group B. Comparative figures for mean age of the patients (5.38 years) has been reported in a randomized controlled trial by Marsal on efficacy and tolerance of topical application of potassium hydroxide $(10 \%$ and $15 \%)$ in treatment of Molluscum Contagiosum. ${ }^{4} \mathrm{~A}$ systematic review on epidemiology of Molluscum Contagiosum in children by Olsen et al. also showed that it was most common among children between 0 and 14 years of age ${ }^{8}$.

In this study, female gender was predominantly affected by Molluscum contagiosum lesions. However, a study done by Laxmisha et al, opposes these findings and observed that more male children were affected by Molluscum contagiosum as compared to female children. ${ }^{9}$

In the present study $85 \%$ of patients with Molluscum contagiosum using Salicylic Acid and Lactic Acid combination and $72.5 \%$ of patients using $10 \% \mathrm{KOH}$ solution showed complete remission and the difference was statistically significant. This finding is supported by the work done by Köse et al ${ }^{5}$. A study done to evaluate the efficacy and safety of $10 \%$ potassium hydroxide solution in the treatment of pediatric patients with molluscum contagiosum also showed that $10 \%$ potassium hydroxide solution is safe, effective, inexpensive and noninvasive alternative treatment for molluscum contagiosum. ${ }^{10}$ They reported that $92.5 \%$ of patients receiving topical $10 \%$ potassium hydroxide solution had complete remission of the lesions in an average duration of 4 weeks. Local side effect of hypopigmentation was observed in $32.4 \%$ of patients. ${ }^{10}$ Similarly, a study done by Sequeira et al also found $10 \%$ potassium hydroxide solution to be an effective and safe treatment modality for the pediatric patients with molluscum contagiosum. ${ }^{11}$

The present study showed no statistically significant difference in the side effects in both the groups after stratification of patients according to number of lesions. This finding is also supported by the study results of Kose et al ${ }^{5}$ and Can et al. ${ }^{10}$ Contrary to this, a study showed side effects of mild pain in $55 \%$ of patients, mild burning sensation in $20 \%$ of patients and secondary bacterial infection in $10 \%$ of patients, but in this study topical potassium hydroxide was used in a higher concentration of $20 \%$ instead of $10 \%$. Therefore, it can be inferred that topical potassium hydroxide when used in higher concentration can be associated with local side effects. ${ }^{12}$

The limitations of this study were small sample size that reduced the power of the study and inability to confirm diagnosis of MC by microscopy of skin scrapings, especially in cases with doubfful clinical diagnosis.

\section{Conclusion}

$10 \% \mathrm{KOH}$ solution is as effective as combination of salicylic and lactic acids for treatment of Molluscum contagiosum in pediatric population, however it is associated with side effects of local irritation (30\%) and erythema $(10 \%)$ in a fraction of treated patients. 


\section{References}

1. Jang HS, Kim MR, Oh SH. Unusual manifestation of Molluscum contagiosum: eruptive papules on the face and neck of an immunocompetent patient. Ann Dermatol. 2013; 25(3): 398-9. Doi: 10.5021/ad.2013.25.3.398

2. McCollum AM, Holman RC, Hughes CM, Mehal JM, Folkema AM, Redd JT et al. Molluscum contagiosum in a pediatric American Indian population: incidence and risk factors. PLoS One. 2014; 9(7): e103419. Doi: 10.1371/journal.pone.0103419

3. Marsal JR, Cruz I, Teixido C, Diez O, Martinez M, Galindo $\mathrm{G}$ et al. Efficacy and tolerance of the topical application of potassium hydroxide $(10 \%$ and $15 \%)$ in the treatment of molluscum contagiosum: Randomized clinical trial: Research protocol. BMC Infect Dis. 2011; 11(1): 278. Doi: org/10.1186/1471-2334-11-278

4. Sherwani S, Farleigh L, Agarwal N, Loveless S, Robertson $N$, Hadaschik E et al. Seroprevalence of Molluscum contagiosum virus in German and UK populations. PLoS One. 2014; 9(2): e88734. Doi: 10.1371/journal.pone.0088734

5. Köse O, Özmen I, Arca E. An open, comparative study of $10 \%$ potassium hydroxide solution versus salicylic and lactic acid combination in the treatment of Molluscum contigiosum in children. J Dermatology Treat. 2013; 24(4): 300-4. Doi: 10.3109/09546634.2011.649690
6. Nguyen HP, Tyring SK. An update on the clinical management of cutaneous molluscum contagiosum. Skin Therapy Lett. 2014; 19(2):5-8. PMID: 24740746

7. Forbat E, Al-Niaimi F, Ali FR. Molluscum Contagiosum: Review and update on Management. Pediatric dermatology/ 2017; 34(5): 504-15. Doi: 10.1111/pde.13228

8. Olsen JR, Gallacher J, Piguet V, Francis NA. Epidemiology of molluscum contagiosum in children: a systematic review. Fam Pract. 2014; 31(2):130-6

9. Laxmisha C,Thappa DM and Jaisankar TJ. Clinical profile of Molluscum Contagiosum in children versus adults. Dermatol Online J.2003; 9(5): 1. PMID: 14996374

10. Can B, Topaloglu F, Kavala M, Turkoglu Z, Zindanci I, Sudogan S. Treatment of pediatric molluscum contagiosum with10\% potassium hydroxide solution. J Dermatolog Treat 2014; 25 (3): 246-8. Doi: 10.3109/09546634.2012.697988

11. Sequeira FF, Bala NK, Hundi GK, Martis J. A study on the efficacy of topical $10 \%$ potassium hydroxide in the treatment of Molluscum contagiosum. Muller J Med Sci Res 2016; 7:1-3. Doi: 10.4103/0975-9727.174604

12. Maluki AH, Kadhum QJ. Treatment of Molluscum Contagiosum by Potassium Hydroxide Solution 20\% with and Without Pricking and by Pricking Alone: A Comparative Study with Review of Literature. Int J Dermatol Clin Res 2015; 1(2): 031-041. 